\title{
Enhancement of Soybean (Glycine max L.) Productivity and Profitability through Front Line Demonstrations in Kota District of Rajasthan, India
}

\author{
K.M. Sharma*, M.C. Goyal, Mahendra Singh and Anil Kumar Sharma \\ Krishi Vigyan Kendra, Borkhera, Kota (Rajasthan)-324001, India \\ *Corresponding author
}

\section{Keyw ord s \\ Soybean, B: C ratio, Frontline demonstration, Technological gap \\ Article Info \\ Accepted: \\ 15 March 2019 \\ Available Online: \\ 10 April 2019}

\section{A B S T R A C T}

Soybean is a major kharif crop of Kota district, which accounts for more than 50 percent acreage of kharif sown area of the district. Front line demonstrations (FLD's) on soybean crop were conducted during kharif seasons of year 2016 to 2018 in 140 ha area on 340 farmer's fields in 17 different villages of operational area of Krishi Vigyan Kendra, Kota to demonstrate production potential of improved agro-techniques. Technological interventions demonstrated consisted of use of variety JS 20-29 \& JS 95-60, seed treatment with carbendazim50 WP @ $2.0 \mathrm{~g} / \mathrm{kg}$ seed \& inoculation of rhizobium \& PSB culture, sowing in $30 \mathrm{~cm}$ rows apart, recommended doses of NP fertilizers $(80-40 \mathrm{~kg} / \mathrm{ha})$ and zinc sulphate $20-25 \mathrm{~kg} / \mathrm{ha}$, weed management by application of Sodium acifluorfen 16.5\%+Clodinofop-P 8\% EC @ $1000 \mathrm{ml} / \mathrm{ha} 20-25$ DAS and need based plant protection measures taken as spray of Thiocloprid 24 SC @ $750 \mathrm{ml} /$ ha for girdle beetle, Trizophos 40 EC 1.0 Litre /ha or Indoxcarb 15 EC $300 \mathrm{ml} /$ ha for semilooper. A study of three years data revealed that demonstrated techniques recorded substantially higher soybean yield than that under existing farmer's practice with mean seed yield of $1562 \mathrm{~kg} / \mathrm{ha}$ which represents 26.23 per cent yield enhancement over farmer's practice $(1227 \mathrm{~kg} / \mathrm{ha})$. Improved techniques fetched average net returns of Rs 28313/ha with B:C ratio of 2.05, higher in comparison to farmer's practice (Rs 20019/ha, B:C ratio 1.95). An average additional returns of Rs.10623/ha was obtained due to application of improved techniques with incremental B: C ratio of 4.58. Yield gap analysis showed extension gap in the range of 227 to $370 \mathrm{~kg} / \mathrm{ha}$, emphasizes the need for transferring the feasible improved technologies among farmers to bridge the extension gap. Technology index in the present study varied between 35.16 to 42.20 per cent.

\section{Introduction}

Soybean is a major kharif crop of the district Kota covering more than 50 per cent acreage of total kharif sown area. Soybean was cultivated in area of 164981, 120764 and 127923 ha during kharif seasons of 2016,
2017 and 2018; respectively in the district with average productivity varying in between 950 to $1247 \mathrm{~kg} / \mathrm{ha}$ (GOR, 2018). Major factors responsible for low productivity of soybean in the district includes erratic rainfall, use of old variety seeds due to nonavailability of quality seeds of newly 
recommended varieties, inadequate fertilizer uses, improper crop geometry, use of high seed rate and inadequate management against heavy infestation of weeds and insect pests. There exist ample scope to enhance the average productivity of soybean up to 2000 $\mathrm{kg} / \mathrm{ha}$ by the adoption of improved varieties and improved agro-techniques. Farmers of the Kota district are mostly using seeds of varieties viz. JS 95-60 and JS 93-05. Further, there is practice of sowing crop in closure row spacing of $22.5 \mathrm{~cm}$, rare use of fertilizers, seed treatment is mostly lacking, however, the farmers indiscriminately uses agro-chemicals to combat against heavy infestation of weeds, insect pest particularly girdle beetle, semilooper, tobacco caterpillar etc., but there exists an extension gap in technical knowhow of soybean production technology.

Research for improving agricultural productivity does not serve its purpose till it reaches to the farmer's fields. Organization of frontline demonstrations (FLD's) is most effective tool for transfer of cost-effective technologies among the farmers, because farmers in general, are driven by the perception that 'Seeing is believing'. The main objective of frontline demonstration is to demonstrate newly released crop production and protection technologies and its management practices under different farming situations. Therefore, frontline demonstrations in soybean crop were conducted during kharif seasons of the year 2016 to 2018 on selected farmer's fields of the operational area of Krishi Vigyan Kendra, Kota with the objective of exhibiting the performance of improved cost-effective agro-techniques which could be adapted by the farmers for yield enhancement of soybean.

\section{Materials and Methods}

Frontline demonstrations on soybean crop were conducted during kharif seasons of year
2016 to 2018 in 140 ha area on 340 farmers fields under Rastriya Krishi Vikas Yojna, National Mission on Oilseed \& Oil Palm and National Food Security Mission. Farmer's for the FLD's were selected based on group meeting taking in to consideration mainly the easy accessibility and effective applicability of demonstration technologies. Farmer from 17 different villages of operational area of Krishi Vigyan Kendra, Kota namely Bhandahera, Kishanpura, Karadiya, Gandifali, Khajuri, Kishanpura Takiya, Aton, Chomabibu, Haripura Manjhi, Padasliya, Umarheri, Dungarjya, Godliyaheri, Bagtari, Baluhera and Haripura Nimoda were selected for the demonstrations. Kota District falls under Agro-climatic Zone-V "Humid Southeastern plain zone" of Rajasthan. The climate in the district is semi arid and moderate. Soils of the study area clay loam in texture with low nitrogen, low to medium phosphorus, high in available potassium and widely deficient in zinc. The area under each FLD was kept 0.4 to 0.5 ha with farmers practice as control plots. Technological interventions under demonstration were decided based on technological gap analysis (Table 1). Based on gap analysis, technological interventions demonstrated includes improved variety JS95-60 (kharif 2016\& 2018) \& JS 20-29 (kharif,2017), seed treatment with Carbendazim 50 WP @ 2 g/kg seed \& inoculation with Rhizobium \& PSB cultures, soil treatment with Trichoderma viride@2.5 $\mathrm{kg} / \mathrm{ha}$ (incubated with 20-25 kg FYM), sowing at $30 \mathrm{~cm}$. rows spacing, recommended NP (20:40 kg/ha) and zinc @ 25 kg/ha, weed management by application of Sodium acifluorfen 16.5\%+Clodinofop-P 8\% EC @ $800-1000 \mathrm{ml} / \mathrm{ha}$ at 20-25 DAS and pest management by spray of Thiocloprid 24 SC @ $750 \mathrm{ml} / \mathrm{ha}$ for girdle beetle, Trizophos 40 EC 1.0 Litre /ha or Indoxcarb 15 EC 300 $\mathrm{ml} / \mathrm{ha}$ for semilooper. Selected farmers were provided trainings on improved agrotechniques of soybean. Critical inputs decided 
based on technological gap analysis were provided and other inputs were suggested as per need. Crop was sown during last week of June to second week of July drilled in $30 \mathrm{~cm}$ rows apart.

All steps like site and farmer selection, layout of demonstration, farmer's participation etc. were followed as suggested by Choudhary (1999). Monitoring of FLD sites were done by periodical visits and needful suggestion were given to the farmers. Field days were also organized at crop maturity to demonstrate the impact of FLD among other farmers of the area for horizontal spread of technologies. The crop was harvested during first fortnight of October. Data related to yield and cost particulars were collected separately for FLD and farmers practice. The average prices of inputs and outputs commodities prevailed during each year of demonstrations were taken for calculating cost of cultivation, net return and benefit cost ratio. The technology gap, extension gap and technology index were calculated as suggested by Samui et al., (2000).

Technology gap = Potential yield Demonstration yield

Extension gap $=$ Demonstration yield Farmers yield

Technology index $(\%)=($ Technology gap $/$ Potential yield) $\times 100$

\section{Results and Discussion}

\section{Yield performance}

The data on average yield of soybean obtained over the years under demonstrated improved practice as well as farmers practice are presented in table 2. The data clearly reveals that application of improved technologies resulted in substantially higher soybean yield in comparison to local check (farmer's practice) during all the three years
(2016 to 2018). The average yield of soybean during three years under improved practices ranged from 1445 to $1621 \mathrm{~kg} / \mathrm{ha}$ with mean yield of $1562 \mathrm{~kg} / \mathrm{ha}$ as against average yield ranged from 1218 to $1250 \mathrm{~kg} / \mathrm{ha}$ with mean yield of $1227 \mathrm{~kg} / \mathrm{ha}$ under farmers practice. Comparatively low yield of soybean were observed during kharif 2018 due to heavy rainfall at maturity phase of the crop.

Pooled data over three years revealed that the application of recommended improved practices on farmer fields enhanced the soybean yield to the extent of 18.67 to 30.30 per cent, with mean increase of 26.23 per cent over farmers practice. The higher yield of soybean under improved practices could be ascribed to the use of improved variety seed, proper seed treatment, use of bio-fertilizer inoculants, proper application of fertilizers, herbicide and need based pesticides. Similar results have been also reported earlier by Singh (2018), Meena et al., (2018) and Bhowate et al., (2017).

\section{Yield gap and technology index}

A perusal of data (Table 3) revealed that values for extension gap ranged from 227 to $370 \mathrm{~kg} / \mathrm{ha}$ with a mean value of $335 \mathrm{~kg} / \mathrm{ha}$ during the period of demonstration which emphasizes the need for transferring the feasible improved technologies among farmers to bridge the extension yield gap. Technology gap which imply researchable issues for realization of potential yield ranged from 879 to $1055 \mathrm{~kg} / \mathrm{ha}$, with a mean of 938 $\mathrm{kg} / \mathrm{ha}$ during three years of demonstration.

Higher technological gap during kharif 2018 was due to comparatively low yield resulted from excess rainfall at maturity of the crop. Technology index shows the feasibility of evolved technology at the farmer's field and lower the value of technology index more is the feasibility of the technology (Katare et al., 
2011). Technology index in the present study varied between 35.16 to 42.20 per cent and on pooled basis, its value observed to be 37.52 per cent. Variation in technology index during three seasons might be attributed to dissimilarity in the weather and soil condition.

\section{Profitability of improved techniques}

Economic indicators i.e. gross cost of cultivation, gross returns, net returns and $\mathrm{B}: \mathrm{C}$ ratio and additional returns of front line demonstrations are presented in Table 4.

Data shows that the gross cost for soybean cultivation under demonstrated practice ranged from Rs. 21685 to $24574 /$ ha with a mean value of Rs. 23321/ha against local check where it ranged from Rs.19125 to 22000/ha with an average expenditure of Rs. 20992. The data clearly reveal that demonstrated technologies provided substantially higher net returns than local check i.e. farmers practice during all the years of demonstration. Based on three years data, it is evident that improved practice fetched net returns of Rs 28313 with B:C ratio of 2.05 , higher in comparison to local practice (Rs 20019/ha, B:C ratio 1.95).

Further, it is shown that demonstrated practice provided additional returns to the extent of Rs. 7758 to $13195 /$ ha with pooled value of Rs. 10623with incremental B:C ratio of 4.58 which might be attributed to yield enhancement under demonstration with least additional cost.

Table.1 Technological gap analysis for soybean

\begin{tabular}{|c|c|c|}
\hline $\begin{array}{l}\text { Technological } \\
\text { point }\end{array}$ & Existing Farmer's practice & Recommended improved practice \\
\hline Seed & Variety JS 95-60 & Variety JS 20-29 \\
\hline Seed rate & $100 \mathrm{~kg} / \mathrm{ha}$ & $75-80 \mathrm{~kg} / \mathrm{ha}$ \\
\hline $\begin{array}{l}\text { Seed } \\
\text { treatment }\end{array}$ & $\begin{array}{l}40 \% \text { farmers treat the seeds with } \\
\text { fungicide like carbendazim }\end{array}$ & $\begin{array}{l}\text { Seed treatment with carbendazim 50WP @ } \\
2.0 \mathrm{~g} / \mathrm{kg} \text { seed and inoculation with } \\
\text { Rhizobium and PSB cultures }\end{array}$ \\
\hline Soil treatment & No soil treatment & $\begin{array}{l}\text { Soil treatment by Trichoderma viridie @ } 2.5 \\
\mathrm{~kg} / \mathrm{h} \text { (mixed with } 20-25 \mathrm{FYM} \text { ) }\end{array}$ \\
\hline $\begin{array}{l}\text { Crop } \\
\text { geometry }\end{array}$ & Sowing crops in $22.5 \mathrm{~cm}$ rows & Sowing crops in $30 \mathrm{~cm}$ rows \\
\hline $\begin{array}{l}\text { Fertilizer } \\
\text { application }\end{array}$ & $\begin{array}{l}\text { Majority of farmers did not } \\
\text { apply any fertilizer }\end{array}$ & $\begin{array}{l}\text { Fertilizer based on STR or Recommended } \\
\text { doses of NP ( } 20: 40 \mathrm{~kg} / \mathrm{ha}) \text { as basal, Zn @ } \\
20-25 \mathrm{~kg} \text { and sulphur } 40 \mathrm{~kg} / \mathrm{ha}\end{array}$ \\
\hline $\begin{array}{l}\text { Weed } \\
\text { management }\end{array}$ & $\begin{array}{l}\text { Injudicious use of various } \\
\text { weedicide available in market }\end{array}$ & $\begin{array}{l}\text { Weeding \& Hoeing } 20-25 \text { DAS or } \\
\text { Application of Sodium acifluorfen } \\
16.5 \%+\text { Clodinofop-P } 8 \% \text { EC @ 800-1000 } \\
\mathrm{ml} / \text { ha at } 20-25 \text { DAS }\end{array}$ \\
\hline $\begin{array}{l}\text { Insect-pest } \\
\text { management }\end{array}$ & $\begin{array}{l}\text { Indiscriminate use of high cost } \\
\text { insecticides eg. Coragen }\end{array}$ & $\begin{array}{l}\text { Spray of Thiocloprid } 24 \text { SC @ } 750 \mathrm{ml} / \mathrm{ha} \text { for } \\
\text { girdle beetle, Trizophos } 40 \mathrm{EC} 1.0 \mathrm{Litre} / \mathrm{ha} \\
\text { or Indoxcarb } 15 \text { EC } 300 \mathrm{ml} / \mathrm{ha} \text { for } \\
\text { Semilooper. Spray water solution } 500-600 \\
\text { litre/ha }\end{array}$ \\
\hline
\end{tabular}


Table.2 Yield performance of soybean under frontline demonstrations in Kota district

\begin{tabular}{|c|c|c|c|c|c|c|c|}
\hline \multirow{2}{*}{$\begin{array}{l}\text { Season \& } \\
\text { Year }\end{array}$} & \multirow[t]{2}{*}{ Variety } & \multirow{2}{*}{$\begin{array}{l}\text { No. of } \\
\text { FLD }\end{array}$} & \multirow{2}{*}{$\begin{array}{c}\text { Area of } \\
\text { FLD } \\
\text { (ha) }\end{array}$} & \multicolumn{2}{|c|}{ Yield (kg/ha) } & \multirow{2}{*}{$\begin{array}{l}\% \text { increase in } \\
\text { yield over FP }\end{array}$} & \multirow{2}{*}{$\begin{array}{c}\text { District average } \\
\text { yield (kg/ha) }\end{array}$} \\
\hline & & & & IT & FP & & \\
\hline Kharif 2016 & JS 95-60 & 140 & 60.0 & 1620 & 1250 & 29.60 & 1016 \\
\hline Kharif 2017 & JS 20-29 & 125 & 50.0 & 1621 & 1244 & 30.30 & 1247 \\
\hline Kharif 2018 & JS 95-60 & 75 & 30.0 & 1445 & 1218 & 18.67 & 950 \\
\hline & & & Mean & 1562 & 1227 & 26.23 & 1071 \\
\hline
\end{tabular}

IT- Improved techniques

FP- Farmer's local practice

Table.3 Yield gap and technology index under frontline demonstrations of soybean

\begin{tabular}{|c|c|c|c|c|}
\hline Season \& Year & $\begin{array}{c}\text { Potential Yield } \\
\text { (kg/ha) }\end{array}$ & $\begin{array}{c}\text { Extension Gap } \\
\text { (kg/ha) }\end{array}$ & $\begin{array}{c}\text { Technology Gap } \\
\text { (kg/ha) }\end{array}$ & $\begin{array}{c}\text { Technology } \\
\text { Index (\%) }\end{array}$ \\
\hline Kharif 2016 & 2500 & 370 & 880 & $\mathbf{3 5 . 2 0}$ \\
\hline Kharif 2017 & 2500 & 377 & 879 & $\mathbf{3 5 . 1 6}$ \\
\hline Kharif 2018 & 2500 & 227 & 1055 & $\mathbf{4 2 . 2 0}$ \\
\hline Mean & $\mathbf{2 5 0 0}$ & $\mathbf{3 3 5}$ & $\mathbf{9 3 8}$ & $\mathbf{3 7 . 5 2}$ \\
\hline
\end{tabular}

Table.4 Economic indicators under of frontline demonstration of soybean

\begin{tabular}{|c|c|c|c|c|c|c|c|c|c|c|}
\hline \multirow[t]{2}{*}{$\begin{array}{l}\text { Season \& } \\
\text { Year }\end{array}$} & \multicolumn{2}{|c|}{$\begin{array}{l}\text { Gross cost of } \\
\text { cultivation } \\
\text { (Rs./ha) }\end{array}$} & \multicolumn{2}{|c|}{$\begin{array}{l}\text { Gross Return } \\
\quad \text { (Rs./ha) }\end{array}$} & \multicolumn{2}{|c|}{$\begin{array}{l}\text { Net Returns } \\
\text { (Rs./ha) }\end{array}$} & \multicolumn{2}{|c|}{$\begin{array}{l}\mathrm{B}: \mathrm{C} \\
\text { ratio }\end{array}$} & \multirow[t]{2}{*}{$\begin{array}{l}\text { Additional } \\
\text { Returns } \\
\text { (Rs./ha) }\end{array}$} & \multirow[t]{2}{*}{$\begin{array}{c}\text { Incremental } \\
\text { B:C ratio }\end{array}$} \\
\hline & IT & $\mathbf{F P}$ & IT & FP & IT & FP & IT & $\mathbf{F P}$ & & \\
\hline Kharif 2016 & 21685 & 19125 & 47790 & 36875 & 26105 & 17750 & 2.20 & 1.93 & & 4.26 \\
\hline Kharif 2017 & 23705 & 22000 & 56735 & 43540 & 33030 & 21540 & 2.39 & 1.98 & 13195 & 7.74 \\
\hline Kharif 2018 & 24574 & 21850 & 50377 & 42618 & 25803 & 20768 & 2.05 & 1.95 & 7758 & 2.85 \\
\hline Mean & 23321 & 20992 & 51634 & 41011 & 28313 & 20019 & 2.05 & 1.95 & 10623 & 4.58 \\
\hline
\end{tabular}

Higher cost benefit ratio and additional returns clearly shows that demonstrated techniques were found cost effective as well as feasible for yield enhancement of soybean on farmer's fields.

Farmer's were also found greatly convinced with the technological interventions due to higher economic returns with least additional investment and management practices. The variation in cost benefit ratio during different years might be due to variation in yield performance and input output cost in that particular year.
In conclusion, the present study on performance of front line demonstrations in soybean clearly indicates that the soybean productivity can be enhanced and yield gap may be minimized on farmer fields with the application of cost-effective improved technological interventions on farmers' fields. There is need of transfer adoptable technologies suitable for enhancing the productivity of soybean crop through conducting of such demonstrations. Technological and extension gaps can be bridged by popularizing package of practices 
with emphasis on improved variety seed, seed treatment, sowing at proper row spacing, integration of bio-fertilizer inoculants and recommended doses of fertilizers for proper crop nutrition, weed management practices and integrated pest management techniques.

\section{Acknowledgement}

The authors are thankful to the Director Extension Education, Agriculture University Kota and Director, ATARI, Zone II, Jodhpur (ICAR) for providing financial assistance towards conducting these front line demonstrations.

\section{References}

Bhowate, R.T., M.B. Dhole and Olambe, A.P. 2017. Impact of Front Line Demonstration on Soybean in Hingoli District of Maharashtra, India. Int.J.Curr.Microbiol.App.Sci. $\quad 6(9)$ : 3098-3102. doi: https://doi.org/10. 20546/ ijcmas.2017.609.381

Choudhary, B. N. 1999. Krishi Vigyan Kendra - A guide for KVK managers. Publication, Division of Agricultural Extension, ICAR. pp 73-78

GOR (2018). Agriculture statistics.
Agriculture port. Department of Agriculture, Government of Rajasthan

Katare, S., S.K. Pandey and M. Mustafa. 2011. Yield gap analysis of Rapeseedmustard through front line demonstrations. Agric. Update, 6(2): 57.

Meena, D.S., Chaman Jadon, C.B. Meena, B.S. Meena, B.L. Meena and Patidar, B.K. 2018. Impact Assessment of Improved Technology on Soybean Productivity in South Eastern Rajasthan, India. Int. J. Curr. Microbiol. App. Sci. 7(07): 728-732. doi: https://doi.org/10.20546/ijcmas.2018.70 7.089

Samui S K, S. Maitra, D. K. Roy, A. K. Mondal and D. Sahu.2000. Evaluation of front line demonstration on groundnut. Journal of Indian Society of Costal Agricultural Research 18(2): 180-306.

Singh, S.B. 2018. Impact of Frontline Demonstrations on Yield of Soybean (Glycine max L. Merril) under Rainfed Conditions in Uttarakhand, India. Int.J.Curr.Microbiol.App.Sci. $\quad 7(05)$ : 986-992. doi: https://doi.org/10.20546/ ijcmas.2018.705.122

\section{How to cite this article:}

Sharma, K.M., M.C. Goyal, Mahendra Singh and Anil Kumar Sharma. 2019. Enhancement of Soybean (Glycine $\max$ L.) Productivity and Profitability through Front Line Demonstrations in Kota District of Rajasthan, India. Int.J.Curr.Microbiol.App.Sci. 8(04): 1808-1813. doi: https://doi.org/10.20546/ijcmas.2019.804.209 